scholarly interpretation of Tertullian's writings. ${ }^{80}$ While this project primarily concerns itself with Tertullian's African identity, in one sense Tertullian is a case study for the usefulness of identity theory in Historical Theology.

\title{
1.3 Patristic Readings of Tertullian
}

In order to review the scholarly assertions on Tertullian's biographical information, it will prove helpful to return to Bardenhewer's summary - cited in full in this introduction. His synopsis will provide the outline for a discussion of the research into Tertullian's life: his name, his birth, his father, his education, his occupation (a jurist, which will call into question his relationship to sophistry and philosophy), his conversion, his ordination, and his schism. Since most scholars now agree with Bray's conclusion that "we know virtually nothing about Tertullian's life," the evolution from the general consensus of scholars in Bardenhewer's time to the accepted axiom of Bray will be presented here, not in a purely chronological form, but thematically. ${ }^{81}$ The scholar who most persuasively contested the life of Tertullian as outlined above, Timothy David Barnes, will be followed closely in the following paragraphs. ${ }^{82}$ The following section will outline and illustrate the debate over Tertullian's life, showing the issues affecting the deconstruction of Tertullian's biography by recent scholars.

scholarly fiction," see Fiorenza, "'You are not to be Called Father': Early Christian History in a Feminist Perspective," Cross Currents 29 (3 1979): $301-23$.

80 Judith M. Lieu, Christian Identity in the Jewish and Graeco-Roman World, (OUP: 2004), 15-7, argues for this move specifically for theories of identity in first and second century Christianity. Similarly, J. Patout Burns, Jr., Cyprian the Bishop, (London: Routledge, 2002), applies Mary Douglas' approach to group identity and boundaries. Also, Maureen A. Tilley, The Bible, 6, has suggested the use of sociology of religion in studying the Donatist controversy. For a sociological reading of early Christian history in general, see Rodney Stark, The Rise of Christianity: A Sociologist Reconsiders History, (Princeton: Princeton University Press, 1996). For an attempt to set theology and anthropology in dialogue more generally, see Douglas $\mathbf{J}$. Davies, Anthropology and Theology, (Oxford: Berg, 2002).

81 Bray, Holiness, 8-9.

82 T.D. Barnes, Tertullian: An Historical and Literary Study, (Oxford: Clarendon Press, 1971). For pre-Barnesian bibliography of Tertullian studies up to 1954 , see CCSL I, xii-xiv; and the website by Roger Pearse, http://www.tertullian.org; although it is sometimes tenuous to cite webpages in scholarly works, a number of recent scholarly reviews have brought Pearse's work into the mainstream of Tertullian scholarship: Revue d'Études Augustiniennes 44 (1998): 339; Ian L.S. Balfour, "Tertullian on and off the Internet," JECS 8 (4 2000), 581; Dunn, Tertullian, 1; Pierre Petitmengin, Revue d'Études Augustiniennes 50 (2004): 393; and Vincent Hunink, Tertullian: De Pallio, (Amsterdam: J.C. Gieben, 2005), 12. 


\subsubsection{Tertullian's Name}

In the last line of the treatise De baptismo, remains one of the few of Tertullian's direct references to himself: "This only I pray, that as you ask you also have in mind Tertullian, a sinner." ${ }^{, 3}$ Beyond this humble self-designation as "sinner," Tertullian felt no need to give the complete form of his name as found in Bardenhewer. In the only other time Tertullian offers his name in his writings, he adds his gentilicium, by concluding, "May peace and grace from our Lord Jesus Christ redound: as likewise to Septimius Tertullianus, whose this tractate is." The Septimii of North Africa were predominantly of humble status in Tertullian's time, with the notable exception of those from Lepcis Magna, including the first Roman emperor of African descent, Septimius Severus (146-211). ${ }^{85}$ Tertullian's full name including his cognomina is not found in the records until it appears on several of the medieval manuscripts. Barnes accepts these as reliable on the basis that there is no cause to suspect them, and from them he deduces that Tertullian's family might have "occupied a low position on the social scale," but he later admits that even this is conjectural and no real conclusion can be reached by Tertullian's name. ${ }^{86}$ The only other information available in the witnesses regarding Tertullian's name comes from the simple appellation, "Tertullian the African," given by Jerome in his translation of the Chronicon. ${ }^{87}$ This title, however, is rarely discussed among Tertullian scholars. Since no biographical information can be deduced from Tertullian's name, scholars have focused on other aspects of his life, such as his place of birth.

\subsubsection{Tertullian's Birth}

Many Septimii, the family or clan to which Tertullian belonged, lived in and around Lepcis Magna, one of the larger Punic cities of Tripolitania. Neither Tertullian nor any other ancient witness, however, claimed Lepcis as his place of birth. Jerome, one of the earliest witnesses on Tertullian, claimed that he was from the city of Carthage in Africa Proconsularis. ${ }^{88}$ Scholars have no evidence that he was of noble birth or whether or not he had citizenship. Tertullian's writings seem to indicate that he wrote from the provincial capital; however, when it comes to determining his place of birth, Jerome is the only extant witness,

83 tantum oro, ut cum petitis etiam Tertulliani peccatoris memineritis. cf. De res. carn. 59.3, on his adultery.

84 De uirg. uel., 17: pax et gratia a domino nostro lesu redundet cum Septimio Tertulliano, cuius hoc opusculum est.

85 Barnes, Tertullian, 242.

86 Ibid, 242-3.

87 16.23-4: Tertullianus Afer.

88 De uiris illustribus 53.1: prouinciae Africae, ciuitatis Carthaginiensis. 
and scholars have not always found him reliable, as in the case of Tertullian's father.

\subsubsection{Tertullian's Father}

In the past, scholars such as Bardenhewer accepted Jerome's claim that Tertullian's father was a centurio proconsularis. Barnes, however, challenged this assertion, citing that this office did not even exist in the ancient Roman Empire of Tertullian's era. ${ }^{89}$ The explanation for Jerome's claim comes from a passage in Tertullian's Apologeticum:

Babes were sacrificed publicly to Saturn in Africa till the proconsulate of Tiberius, who exposed the same priests on the same trees that overshadow the crimes of their temple, on dedicated crosses, as is attested by the soldiery of my father, which performed that very service for that proconsul. ${ }^{90}$

Barnes conjectures that Jerome's text had a variant reading that replaced patriae nostrae with patri nostri. ${ }^{91}$ Barnes exhausts the evidence for child sacrifice in Africa arguing for the improbability of the Punic practice to have continued so late as to be witnessed by Tertullian's father. ${ }^{92}$ Therefore, without Tertullian claiming his father a proconsular centurion (which the variant reading implies), no validation remains for his father to have even been a soldier, much less to have attained the rank of officer. ${ }^{93}$ Without any knowledge of Tertullian's social rank or background being evident, scholars must surmise his status and upbringing from his education.

\subsubsection{Tertullian's Education}

The fluid style and rhetorical skill of Tertullian is noticable throughout his writings, and, as one of the first Christians to have written in Latin, he also

89 Tertullian, 13-21.

90 Apol. 9.2: Infantes penes Africam Saturno immolabantur palam usque ad proconsulatum Tiberii, qui eosdem sacerdotes in eisdem arboribus templi sui obumbratricibus scelerum uotiuis crucibus exposuit, teste militia patriae nostrae, quae id ipsum munus illi proconsuli functa est.

91 As represented in the translation given, wherein Souter notes the patriae nostrae in the text, but chooses the patri nostri reading. These exact variants are preserved in the Fuldensis manuscript of the Apologeticum. Similarly, the CCSL, which reads patri nostri relying on Jerome. For this textual tradition, see C. Becker, Tertullian: Apologeticum, (Munchen: Kosel-Verlag, 1961), 229ff.; for a general discussion of the manuscripts of Tertullian's works, see the prafatio to CCSL, vol. 1, ed. Dom Eligius Dekkers, (1954).

92 However, James B. Rives, "Tertullian on Child Sacrifice," Museum Helveticum 51 (1994): 5463, disputes Barnes' claim.

93 See also Bray, Holiness, 33, on Jerome's unreliability in this instance. 
published several works in Greek, indicating a high level of education. ${ }^{94}$ Not only was Tertullian trained in the Greek language, but he was also schooled in the Greek classics. Jean Daniélou asserts, "Certainly, it was Greek Christian thought, both orthodox and heterodox, which was Tertullian's primary antecedent.".95 Tertullian, without necessarily declaring his own schooling, lists both the Roman and the Greek classical authors taught in the schools of Carthage and Africa. ${ }^{96}$ Because of his breadth of knowledge of Roman and Greek history and thought, and because of his abilities as a communicator, it should be assumed that Tertullian received a high standard of education. ${ }^{97}$

\subsubsection{Tertullian's Occupation}

One of the most controversial aspects of Tertullian's life is the claim that he was a jurist, a claim which dates back to Eusebius, who stated that Tertullian was "a man well versed in the laws of the Romans, and in other respects of high repute, and one of those especially distinguished in Rome." ${ }^{98}$ Adolf von Harnack in his attempts to trace the development of dogma from the New Testament found that Tertullian did not insert Platonist ideas into his Christianity like the many Eastern Fathers. Instead, Harnack found in Tertullian a reliance on Roman legalism, which to Harnack was supported by Eusebius' witness. ${ }^{99}$ Agreeing with Harnack, A. Beck argued that the Christian Tertullian of Carthage was Tertullianus the Roman jurist who wrote at least one legal reference book, De castrensis peculio, and some eight books of questiones. ${ }^{100}$

The conclusions of Harnack and Beck became the consensus among scholars until Barnes challenged the logic of the argument. ${ }^{101}$ According to Barnes, the mere coincidences of names and time periods do not merit the conclusion that the two Tertulliani were the same person. ${ }^{102}$ Moreover, Eusebius uses Tertullian on a point of law mentioned in the Apologeticum and so he exaggerates Tertullian's expertise to make him more credible. ${ }^{103}$ Even without his arguments for the improbability of Tertullian the Christian having been a iurisconsultus, Barnes laid

94 See De bapt. 15; De cor. 6; De uirg. uel. 1.

95 The Origins, xiii, and 272.

96 Ad nat. 2.7,13; Apol. 12, 14, 50; De praes. haer. 39; De an. 20, 42; De res. carn. 1.

97 Dunn, Tertullian, 5 , an "elite" education.

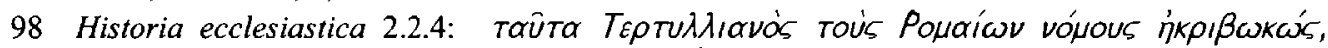

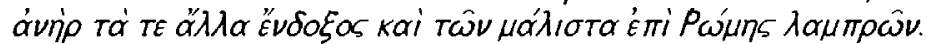

99 Die Chronologie der Altchristlichen Literatur bis Eusebius II, (Leipzig, 1904), 256ff; as reviewed by Bray, Holiness.

100 Römisches Recht bei Tertullian und Cyprian, (Aalen, 1930); referencing the Digesta and the Codex Iustinianus, cited in Bames, Tertullian, 22.

101 Barnes, Tertullian, 22ff.

102 Ibid, 24.

103 Ibid, 26. 
bare the lack of evidence for such a claim which is why scholars are in general agreement with Barnes on this point. ${ }^{104}$

Barnes' conclusion had a wide impact on the scholarly understanding of Tertullian, both in his life and in his writings. Because Tertullian was assumed to have been the Roman jurist, debate ranged over when he lived in Rome. J. Quasten summarized the pre-Barnes majority view that Tertullian did live in Rome, but he provides no conjecture as to the dates. ${ }^{105}$ Without the claim that Tertullian of Carthage was the Roman jurist, recent scholarship has largely ignored the question. ${ }^{106}$

Gerald Bray has catalogued the trend of past scholars who followed the conclusions of Harnack and discovered legal terminology in Tertullian. ${ }^{107}$ The Sonderprache School, writing in Holland in the early decades of the twentieth Century, led by Mgr. Schrijnen, forwarded the theory of a special Christian language that adapted secular terms, such as persona and substantia. Many word studies of Tertullian found legal terminology in his writings and declared his theology formed by the legal context. After Barnes, however, scholars began to reevaluate the presuppositions of these word studies, concluding with different results. $^{108}$

With the option of jurist excluded from Tertullian's education and career, a majority of scholars have returned to the argument of Siegmund Schlossmann. ${ }^{109}$ Because he rejected Harnack's claim that Tertullian was a lawyer, Schlossmann was not widely accepted in his time. Instead of concluding Tertullian was a jurist, Schlossmann interpreted Tertullian as a rhetorician. Two scholars who more recently championed this understanding of Tertullian are R. Sider and Jean-

104 For a more recent review of the arguments, see David I. Rankin, "Was Tertullian a Jurist?" $S P$ 31 (1997): 335-342; and Wright, "Tertullian," 1032-3, explaining the benefits of "the move away from reading Tertullian in the categories of Roman law."

105 Patrology II, (1963), 246.

106 Barnes, Tertullian, 244-5, preempted the use of uidemus Romae in De cul. fem.1.7.2 as evidence, arguing that this could be a device like is often found in Virgil; ref. Georgica 1.472. Although he admits the statement could be "rhetorical flourish," Dunn, Tertullian, 4, does believe Tertullian went to Rome "at some stage."

107 Bray, Holiness, $158 \mathrm{ff}$.

108 René Braun, Deus Christianorum: Recherches sur le vocabulaire doctrinal de Tertullien, rev. ed. (Paris: Études Augustiniennes, [1962]1977), rejects Harnack's proposal that Tertullian's usage is juridic. However, Bray, "Legal Concept of Ratio in Tertullian," VC 31 (1977), 94-116, says that even though Tertullian was not a jurist, he used the term ratio in a legal sense and not in a Stoic sense for the divine Logos. J. Albert Harrill, "The Influence of Roman Contract Law on Early Baptismal Formulae (Tertullian, Ad Martyras 3)" SP 35 (2001), 275-82, concurs with Bray. Osborn, Tertullian, 138, says Tertullian used persona in both a legal and a philosophical sense without ever defining the term. Recently, however, Maureen A. Tilley, The Bible in Christian North Africa, (Minneapolis, Minn.: Fortress Press, 1997), 23, believes him to be a jurist.

109 "Tertullian im Lichte der Jurisprudenz," Zeitschrift für Kirchengeschichte 27, (1906): 251-75, 407-30; cited in Bray, Holiness, 17. 
Claude Fredouille, and many now see Tertullian, not as a legal expert, but as a rhetorical genius capable of persuading with a whole range of imagery, including legal imagery. ${ }^{110}$

The title of sophist for Tertullian provides scholars with another frame of reference in which to place him, and most believe Tertullian relied on the GraecoRoman classics of oratory skill such as taught by Cicero and Quintilian. ${ }^{111}$ More specifically, scholars can now look to the Second Sophistic movement for the context from which Tertullian writes. Geoffrey Dunn explains how scholars like Sider and Barnes "demonstrated that classical rhetoric provided an important tool for Tertullian in crafting his treatises." 12 With such a training providing the framework for Tertullian's vocabulary and arguments, scholars could also ask whether Tertullian could be understood as a philosopher.

Because of Tertullian's enigmatic statements, such as "credible because inept," scholarly debate has often centered on Tertullian's stance towards philosophy. ${ }^{113}$ Bray gives a recount of August Neander's work, which Bray calls the "beginning of modern scholarly work on Tertullian." 114 Neander, along with his tutor, Friedrich Schleiermacher, reacted to Kant seeing Tertullian through the lens of German pietism as the first defender of the Faith against Rationalism (i.e. Gnosticism.) In the last few decades, scholars have been more divided in their understanding of Tertullian's appreciation and use of philosophy.

Arguing most vigorously for an understanding of Tertullian as a philosopher is Eric Osborn. ${ }^{115}$ To Osborn, philosophy is an integral aspect of theology, and he therefore denies that Tertullian's "credible because it is inept" is a defense of irrationalism or fideism. ${ }^{116}$ Instead, he claims that this specific statement is an oratory device only applicable to the incarnation, not to all philosophical propositions. ${ }^{117}$ Osborn presents his case for Tertullian's use of philosophy: "[Tertullian] knows his philosophers better than do most Greek fathers. Tertullian does not hide his sympathy for Seneca $(A n .20 .1)$ nor his genuine regret that all heretics have seasoned their works with Plato (An. 23.5). Yet Christian

110 Sider, Ancient Rhetoric and the Art of Tertullian. (OUP, 1971); Fredouille, Tertullien et la Conversion de la Culture Antique, (Paris: Études Augustiniennes, 1972) 482-5, argues that Tertullian's training as an orator would have included areas of law, philosophy, etc.; Bray, Holiness, 34; but also see Bray's statement (97), "There can be no doubt that a Roman sense of legalism was fundamental to Tertullian's way of thinking"; Rankin, Tertullian, 342.

111 See Sider, Ancient Rhetoric; Fredouille, Tertullien, 481; Barnes, Tertullian, (1971), 22-29, 197. 206, esp. 196; in the title of chapter 14, Barnes calls Tertullian "The Christian Sophist"; Wright, "Tertullian," 1031-2. For earlier bibliography, see Mark S. Burrows, "Christianity in the Roman Forum: Tertullian and the Apologetic Use of History," VC 42 (3 1988), 211-2.

112 Dunn, "Rhetorical Structure in Tertullian's Ad Scapulam," VC 56 (2002): 47.

113 De carn. Chris. 5: credibile est, quia ineptum est.

114 Bray, Holiness, $15 \mathrm{ff}$.

115 Tertullian, First Theologian of the West, (CUP, 1997).

116 Ibid, 56.

117 Ibid, 51. 
artisans readily find the creator God whom Plato declared to be so difficult of discovery and description ( $A$ p. 46.9)." 118 Tertullian's use of philosophy suggests to Osborn that Tertullian is himself a philosopher.

The objection to this understanding of Tertullian on which Osborn must expound is Tertullian's question, "What has Athens to do with Jerusalem?"119 Osborn delineates four possible explanations of Tertullian's Athens/Jerusalem quote: (1) Tertullian is under psychological distress, and as a believer he rejected philosophy, but his own training in philosophy and rhetoric could never be discarded. (2) Tertullian was a product of cultural history. Tertullian is proud of his breadth of knowledge of cultural writers and uses them often, but insists that Christianity is over and above all that the culture can offer. (3) Tertullian is a philosopher who simply believes he has found a better philosophy. (4) Tertullian uses paradox and disjunction to clarify; they are rhetorical devices. ${ }^{120}$ Osborn chooses the last of these possible explanations and proposes that paradox and disjunction are Tertullian's way of "clarifying things" because Tertullian is in fact a Stoic philosopher. ${ }^{121}$

Not all scholars accept the understanding of Tertullian as a Stoic, or for that matter any form of a philosopher. Barnes rejected such an idea outright, saying,

Tertullian would have deplored the attempts of Justin, Clement and Origen to reconcile Christianity and pagan philosophy. He explicitly rejected a Stoic, Platonic or dialectical Christianity. But in a wider sense, he had himself reconciled Christianity and classical culture. For he used the benefits of a traditional education and the fruits of his pagan erudition to defend and to propagate what he considered to be the truth. ${ }^{122}$

More recently, A.J. Vanderjagt has argued that Tertullian rejected philosophy, especially that of Plato, the Stoics, the Aristotelian logicians, and all heretics using them. ${ }^{123}$ The opposing understandings of Tertullian continue to divide scholars. Many, however, attempt to find a via media, allowing for Stoic and other philosophical concepts to be part of Tertullian's language as has been shown with legal terminology, thereby making them less integral.

118 Ibid, 31

119 De praes. haer. 7.9: “What indeed has Athens to do with Jerusalem?" [Quid ergo Athenis et Hierosalymis?]

120 Osborn, Tertullian, 29-37.

121 Ibid, 37; cf. Bray, Holiness, 34ff., who also understood Tertullian as borrowing Stoic ideas.

122 Barnes, Tertullian, 210.

123 "Sensual Evidence in Tertullian and Lactantius," SP 31 (1997): 364. 


\subsubsection{Tertullian's Conversion}

Like most points of Tertullian's life, scholars know very little from Tertullian's writings about his encounter with Christianity: whether or not he was a convert, and, if so, when this came about. Tertullian's rare and brief statements provided past scholars of Bardenhewer's day with enough material to conclude that Tertullian was born of pagan parents and converted to Christianity. ${ }^{124}$ While Barnes did not completely reject the possibility of Tertullian's conversion, he says that the evidence, even within his writings is dubious at best. ${ }^{125}$

\subsubsection{Tertullian's Ordination}

Again relying on the witness of Jerome, some scholars have declared Tertullian to have been a presbyter. Barnes, having demonstrated Jerome unreliable on other aspects of Tertullian's life, challenged this assertion as well. ${ }^{126}$ Twice in his writings, Tertullian seems to indicate that he was a layman. ${ }^{127}$ In light of these readings and with the weight of Barnes' arguments, most scholars agree that Tertullian remained a member of the laity, performing no clerical role. ${ }^{128}$ Scholars also agree that despite the fact that Tertullian served in no official office, he did wield tremendous influence through his writings on the Christian community, especially concerning his alleged schism.

\subsubsection{Tertullian's Schism}

Despite the consensus view before his time, Barnes destabilized the notion of Tertullian as a schismatic, alternatively arguing that the North African writer never intended to sever with the Church officially. ${ }^{129}$ Tertullian was simply the "first great teacher of unimpeachable doctrinal orthodoxy who dared to enunciate

124 Apol. 18.4; 50.15; De paen. 1.1; Ad Scap. 5.5; De res. carn. 59.3; De pat.1.1. More recently, Dunn, Tertullian, 4.

125 Barnes, Tertullian, 245-6.

126 Tertullian, 11, 117.

127 Exhort. cast. 7.3: “And are not we laypersons also priests?" [Nonne et laici sacerdotes sumus?] Rankin, Tertulian and the Church, 39, attributes French scholars' affirmation of Tertullian's ordination to a mistranslation of Tertullian's question in French, reading, "Est-ce que, même laics, nous ne sommes pas prêtres?" cf. De mon. 12.1-4, where within a comparison of clergy and laity he seems to be placing himself among the latter.

128 Barnes, 117ff., does conjecture that Tertullian would have delivered sermons during the Christian meetings. cf. Bray, Holiness, 40-1, who argues that Tertullian was a presbyter, and Jerome actually preserves an example when presbyter and priest were not the same; i.e. the presbyter had no sacerdotal function.

129 See Bray, Holiness, $17 \mathrm{ff}$, for the pre-Barnesian consensus. 
an unpalatable truth: the church is not a conclave of bishops, but the manifestation of the Holy Spirit."130 After Barnes, scholars vacillated over the extent to which Tertullian was a "Montanist."131 Bray discusses the way in which Tertullian would have been declared a heretic postmortem and goes so far as to declare, "It is extremely doubtful whether Tertullian ever met a Phrygian Montanist in the flesh; his first contact with them was most probably through their writings." 132 The discussion hinges on whether or not Tertullian formally disassociated with the broader Christian community. ${ }^{133}$ Representing the more recent consensus, Dunn claims that the past understanding of Tertullian as a schismatic "does not seem sustainable today." "134

\subsubsection{Tertullian, Beyond the "Facts"}

By focusing on various points of Tertullian's life, the above presentation neglects to address a recurring element in the study of Tertullian, namely what many deem to be a strong anti-Roman sentiment in Tertullian's writings. ${ }^{135}$ This sentiment is variously defined and discussed and therefore has remained a nebulous element in scholarly discourse, often evading direct elaboration. Whenever Tertullian's anti-

130 Barnes, Tertullian, 83; ref. De pud. 21.17. It should be noted that Barnes nevertheless did conclude that Tertullian was a Montanist in a schismatic sense.

131 Before Barnes, see H.J. Lawlor, "The Heresy of the Phrygians," The Journal of Theological Studies 9 (1908): 481-99, reprinted in Orthodoxy, Heresy, and Schism in Early Christianity, (New York: Garland Publishing, Inc., 1993). After Barnes, see D. Powell, "Tertullianists and Cataphrygians," VC 29 (1975): 33-54; Bray, Holiness; L.J. van der Lof, "The Plebs of the Psychici: Are the Psychici of De Monogomia Fellow-Catholics of Tertullian?" in Eulogia: Mélanges offerts à Antoon A.R. Bastiaensen à l'occasion de son soixante-cinquième anniversaire, ed. G.J.M. Bartelink, A. HIlhorst and C.H. Kneepkens, (Steenbrugis : In Abbatia S. Petri, 1991), 353-63; Danicl L. Hoffman, The Status of Women and Gnosticism in Irenaeus and Tertullian, (Lewiston: Edwin Mellen Press, 1995), 5; Rankin, Tertullian; William Tabbernee, "To Pardon or not to Pardon? North African Montanism and the Forgiveness of Sins," SP 36 (2001), 377; Christine Trevett, Montanism: Gender, Authority and the New Prophecy, (CUP, 1996), 69, and 73, concludes that he "may properly be described as a Montanist..." but not as a schismatic; Tabernee, Montanist Inscriptions and Testimonia: Epigraphic Sources Illustrating the History of Montanism. (Macon, GA: Mercer University Press, 1997), 54-5; Wright, "Tertullian," 1028-9; Dunn, Tertullian, 6; and Stewart-Sykes, Tertullian, 14-5.

132 Bray, Tertullian, 10-11, and 55. Similarly, Osborn, Tertullian, 212, understands Tertullian to have had no contact with Montanism from Asia Minor, but an altered "African" form in Carthage.

133 See discussion in chapter nine.

134 Tertullian, 6. As for Tertullian starting his own sect of Tertullianistae, as claimed by Bardenhewer who depends on the late witnesses of Augustine (De haeresibus ad Quoduultdeus 86) and the anonymous Praedestinatus (Haeresibus 1.86), most scholars concur with Barnes, Tertullian, 259, that the claim deserves "no place in a study of Tertullian." For discussion, see Tabbernee, Montanist Inscriptions, 475-6; and Trevett, Montanism, 75.

135 See chapter eight. 
Roman attitude is deliberated, it is usually in one of two categories: the debate over his so-called Montanism and his attacks on Roman paganism. ${ }^{136}$

Throughout Christian history, readers of Tertullian have found him antagonistic towards the Roman church. The Donatists claimed Tertullian as their spiritual ancestor in their dispute against the Roman led Catholic church. ${ }^{137}$ In reviewing past understandings of Tertullian, Bray lists several occasions where groups who came in opposition with the Roman church found Tertullian an ally because of his anti-Roman sentiment. ${ }^{138}$ In the fifteenth century, Reformers rediscovered Tertullian's manuscripts for their common polemic against Rome. Later, following the French revolution, many French scholars such as Paul Monceaux returned to the study of the Roman church's claim to Petrine authority and the beginnings of Latin Christianity. ${ }^{139}$ In cataloguing those who read Tertullian as anti-Roman, Bray suggests that a more widely accepted understanding of Tertullian is one who "fights within the Roman system for the fair treatment of Christians." 140 Because more recent scholarship has rejected the claim that Tertullian separated from the Roman Church with the Montanist sect, the problem arises as to how to interpret the anti-Roman attitude so many readers of Tertullian have detected. Was Tertullian simply criticizing the Roman church from within the communion? Perhaps a further explanation is required that addresses the vehemence detected by so many scholars but does not resort to "Montanist teachings" as the cause.

More transparent in Tertullian's writings is his apologetic against the paganism of the Roman Empire. Osborn comments, "Most of what he wrote was directed against someone. He took on the Roman establishment, Marcion, Praxeas, indulgent bishops, Hermogenes and Valentinians; indeed he took on the world itself and insisted that things were going to be very different at the end."141 Osborn represents the majority of scholars who accept Tertullian's attack on the "Roman establishment" as a critique against idolatry and an attack on the unjust treatment of Christians. ${ }^{142}$ Some scholars, however, acknowledge in Tertullian a

136 e.g. Robert F. Evans, One and Holy: The Church in Latin Patristic Thought, (London: SPCK, 1972), 7.

137 See chapter four.

138 Holiness, 11, $21 \mathrm{ff}$., and 37.

139 Histoire littéraire de l'Afrique chrétienne, (Paris, 1901); Monceaux sets Tertullian at the head of the African church with an African personality that tended towards independence and schism; cf. Charles Guignebert, Tertullien, étudies sur sentiments à l'égard de l'emprise de la société civile, (Paris, 1901), argued with Harnack that Tertullian was anti-Roman Catholic; both cited in Bray, Holiness, 21-23.

140 Bray, Holiness, 37.

141 Tertullian, xiv.

142 Osborn, "Tertullian as Philosopher and Roman," in Die Weltlichkeit des Glaubens in der Alten Kirche : Festschrift für Ulrich Wickert zum siebzigsten Geburtstag, ed. Dietmar Wyrwa, (Berlin: Walter de Gruyter, 1997), 231-247. Osborn's conclusion that Tertullian "maintained a positive attitude towards the Roman state" (244), relies on A.Z. Ahondokpe, La vision de Rome chez Tertullien recherchessur le vocabuilaire politique et administratif de Tertullien, 2 vols., 
broader criticism of Romanism. ${ }^{143}$ Did Tertullian attack aspects of the Roman Empire? If Tertullian opposed the Roman government, what were his reasons?

The scholarly awareness of Tertullian's anti-Romanism in relation to both the episcopal and the imperial seats raises questions about Tertullian's identities and loyalties. If Tertullian understands himself as being opposed to and outside of the Roman system, then to what system or category does he belong? Because Tertullian evidences a high degree of education and familiarity with GraecoRoman society, history and customs, scholars often assume that he belongs to the elite class of his time, and that he was implicitly supportive of the overall Roman structure, yet such an understanding of Tertullian does not seem to take sufficient account of his anti-Roman sentiments, nor the colonial presence of Tertullian's period.

Given the lack of Tertullian's biographical information agreed upon by scholars, any indication of self-identity evident in Tertullian's writings invites attention. If Tertullian attacks Rome and Romans, then he evidently sees himself as non-Roman. If Tertullian is not Roman, to what category does he belong? One possible answer is that Tertullian wrote with the self-identity of an African. Therefore, in order to give an introduction to Tertullian and his North African context, the following section consists of a brief chronology of both Roman Africa and the Christianization of Roman Africa. Following the chronological surveys, the remaining chapters will employ theories of identity from Social Anthropology in order to re-read Tertullian's context and his writings.

\subsection{The Context of Tertullian: Colonization of Africa}

Was Tertullian a Tunisian? While one level of discourse might allow scholars to apply such appellations, historians would typically deem such an identification anachronistic. What identities, then, were available to Tertullian, writing from the context of Roman Africa? ${ }^{144}$ In order to explore the possibilities, a brief chronology of Roman colonization of African will prove helpful.

(Lille: A.N.R.T, Université de Lille III, 1992), who finds Tertullian explicitly critical only of Roman idolatry, not the Roman state. It will be suggested below that Tertullian can rhetorically portray Rome in a positive light when it suits his interest and yet still retain an anti-Roman sentiment. It is worth noting that Osborne never cites a passage where Tertullian depicts himself as a "Roman."

143 See bibliography in Osborn, Tertullian, 84; and E. Schüssler Fiorenza, In Memory of Her: $A$ Feminist Theological Reconstruction of Christian Origins, (London: SCM Press, 1983), n. 80; and Fredouille, Tertullian, 446-7.

144 e.g. British? See $A d u$. Iud. 7.4: "...the haunts of the Britons - inaccessible to the Romans, but subjugated to Christ" [...et Britannorum inaccessa Romanis loca Christo uero subdita]. Or Indian? See Apol. 42.1: "We are not Indian Brahmins or Gymnosophists..." [Neque enim Brachmanae aut Indorum gymnosophistae sumus...]. 